\title{
New records of angiosperms from Espírito Santo, Brazil
}

\author{
João Paulo Fernandes Zorzanelli ${ }^{1 *}$, Tatiana Tavares Carrijo ${ }^{2}$, Henrique Machado Dias ${ }^{1}$ and \\ Aderbal Gomes da Silva ${ }^{1}$ \\ 1 Universidade Federal do Espírito Santo, Departamento de Ciências Florestais e da Madeira, Avenida Governador Lindemberg, 316, \\ Centro, CEP 29.550-000, Jerônimo Monteiro, ES, Brazil \\ 2 Universidade Federal do Espírito Santo, Departamento de Biologia, Alto Universitário, s/n, Guararema, CEP 29.500-000 Alegre, ES, Brazil \\ * Corresponding author. E-mail: jp.zorzanelli@gmail.com
}

\begin{abstract}
This study aims to report six new occurrences of angiosperm species from the state of Espírito Santo, widening their geographic distribution. These floristic novelties evidence the presence of knowledge gaps regarding the flora and little collecting effort in Espírito Santo, in addition to demonstrating the floristic importance of Serra do Valentim, with restricted distribution species.
\end{abstract}

Key words: floristic, taxonomy, biogeography, distribution gaps

Alexander Curt Brade published in 1947 the first scientific contribution about the flora of Espírito Santo. This paper was a monograph on Lycophytes and Ferns. Subsequently, Ruschi (1986) published a checklist of Orchidaceae, revealing the overwhelming diversity of this family in the state. In the last five years, 18 new species to science were described in regional floras and taxonomic revisions based on collections from Espírito Santo. Some of these species are endemic to the state and known only for a few collections, such as Vriesea euclidiana Leme \& G.K. Br. (Bromeliaceae; Leme et al. 2010), Casearia espiritosantensis R. Marquete \& Mansano (Salicaceae; Marquete \& Mansano 2010), Dorstenia romaniucii A. Ferreira \& M. D. M.Vianna (Moraceae; Machado \& Viana Filho 2012), Tibouchina tedescoi Meirelles, L. Kollmann \& R. Goldenb. (Melastomataceae; Meirelles et al. 2012), Leandra reptans R.Goldenb. \& Reginato (Melastomataceae; Goldenberg \& Reginato 2013), Leandra cristata Reginato \& R.Goldenb. and Leandra fontanae Reginato \& R.Goldenb. (Melastomataceae; Reginato \& Goldenberg 2013), Markea atlantica Stehmann \& Giacomin (Solanaceae; Stehmann \& Giacomin 2012), Aristolochia subglobosa J.Freitas, Lírio \& F.González (Aristolochiaceae; Freitas et al. 2013), Prepusa dibotrya Fraga, A.P. Fontana \& L.Kollmann (Gentianaceae; Fraga et al. 2014), Eugenia amorimii Fraga \& Giareta and Eugenia sobraliana Giaretta \& Fraga (Myrtaceae; Giaretta \& Fraga 2014. Nevertheless, the knowledge brought by local floras also provided new insights about the plant richness of Espírito Santo.

Local floras for a wide geographical range of municipalities were produced in the last years. Floras of Begoniaceae (Kollmann 2006), Melastomataceae (Goldenberg \& Reginato 2006) and Gesneriaceae (Rossini 2010) added important information on the flora of Santa Teresa. Bromeliaceae was investigated with greater emphasis in the southern Espírito Santo, resulting in checklists for Cachoeiro de Itapemirim (Krahl et al. 2012) and Mimoso do Sul (Couto et al. 2013). Arecaceae was studied at Linhares (Coelho 2010), in the urban area of Vila Velha (Valadares et al. 2012), and in the Biological Reserve of Duas Bocas (Cariacica municipality) by Lima and Soares (2003). Melastomataceae was also studied in the Pedra Azul State Park at Domingos Martins municipality (Meirelles \& Goldenberg 2012). The species of Orchidaceae (Fraga \& Peixoto 2004) and Sapotaceae (Fabris \& Peixoto 2013) were monographed in "tabuleiro" forest. Chiron \& Bolsanello (2011) published novelties for the genus Acianthera, and Chiron (2013) for the subfamily Epidendroideae (except for the tribe Maxillarieae) in the entire state.

Despite these valuable contributions, some regions such as the northeastern Espírito Santo and the Caparaó region, have received smaller attention in terms of floristic studies. This is a cause of concern, since these areas are under strong threat of suppression due to the expansion of agriculture and the extraction of ornamental rocks. This is the case of Serra do Valentim (Figure 1), that comprises the largest remnant of Atlantic Forest of Iúna municipality. Its vegetation was studied between the years 2011 and 2012 (Zorzanelli 2012) and supplemented by collections during the year of 2013 . This inventory revealed six new occurrences for the Espírito Santo state: Acalypha amblyodonta (Müll.Arg.) Müll.Arg. (Euphorbiaceae), Anthurium lucioi Nadruz (Araceae), Cissus trianae Planch. (Vitaceae), Ocotea villosa Kosterm. (Lauraceae), Tovomitopsis paniculata (Spreng.) Planch. \& Triana, and Velloziella dracocephaloides (Vell.) 


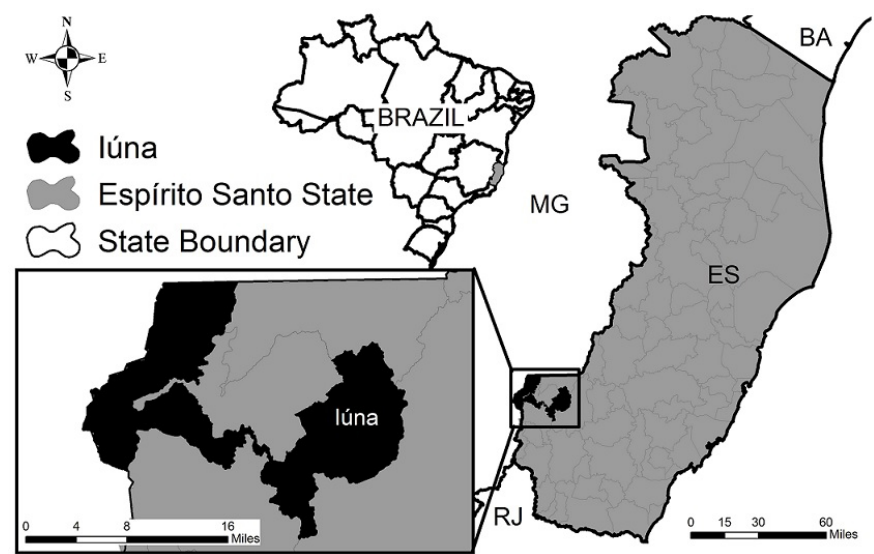

Figure 1. Map showing the location of lúna Municipality, Espírito Santo state, Brazil.

Baill. (Orobanchaceae). Vouchers of these new records were incorporated to the VIES, HRCB and RB Herbaria (acronyms according to Holmgren etal.1990). Specialized literature, including monographs and scientific articles were used to identify species. Subsequently, experts in the referred families confirmed their identification. Geographic distributions were checked by referring to scientific articles, monographs, and by the on-line, databases speciesLink and "Lista do Brasil" (Forzza et al. 2010). Descriptions followed the terms and concepts of Hickey and King (2002). The new records of angiosperms for Espírito Santo state are listed below.

Acalypha amblyodonta (Müll.Arg.) Müll. Arg. in Mart., Fl. Bras. 11(2): 365. 1874. (Figure 2a).

Shrub 1-1.5 m; stems round covered with lanose hairs; leaves alternate, blades ovate covered with pannose hairs, base round, apex acute, margin serrate; inflorescence axillar raceme, pilose, espiciform and bisexual.

Notes: Acalypha amblyodonta is a variable species. Lucena \& Alves (2010) wrote that the four variants recognized by Müller (1874) in Flora Brasiliensis (i.e., A. amblyodonta var. hispida, A. amblyodonta var. villosa, $A$. amblyodonta var. gaudichaudii and $A$. amblyodonta var. repanda) occur in Minas Gerais and Rio de Janeiro States. Cardiel (2014), in "Lista de Espécies da Flora do Brasil", expanded the distribution of the species for São Paulo, Paraná and Goiás states. An illustration of $A$. amblyodonta var. villosa is available in Müller (1874: pl. 53).

MATERIAL EXAMINED: Iúna, road for the Serra do
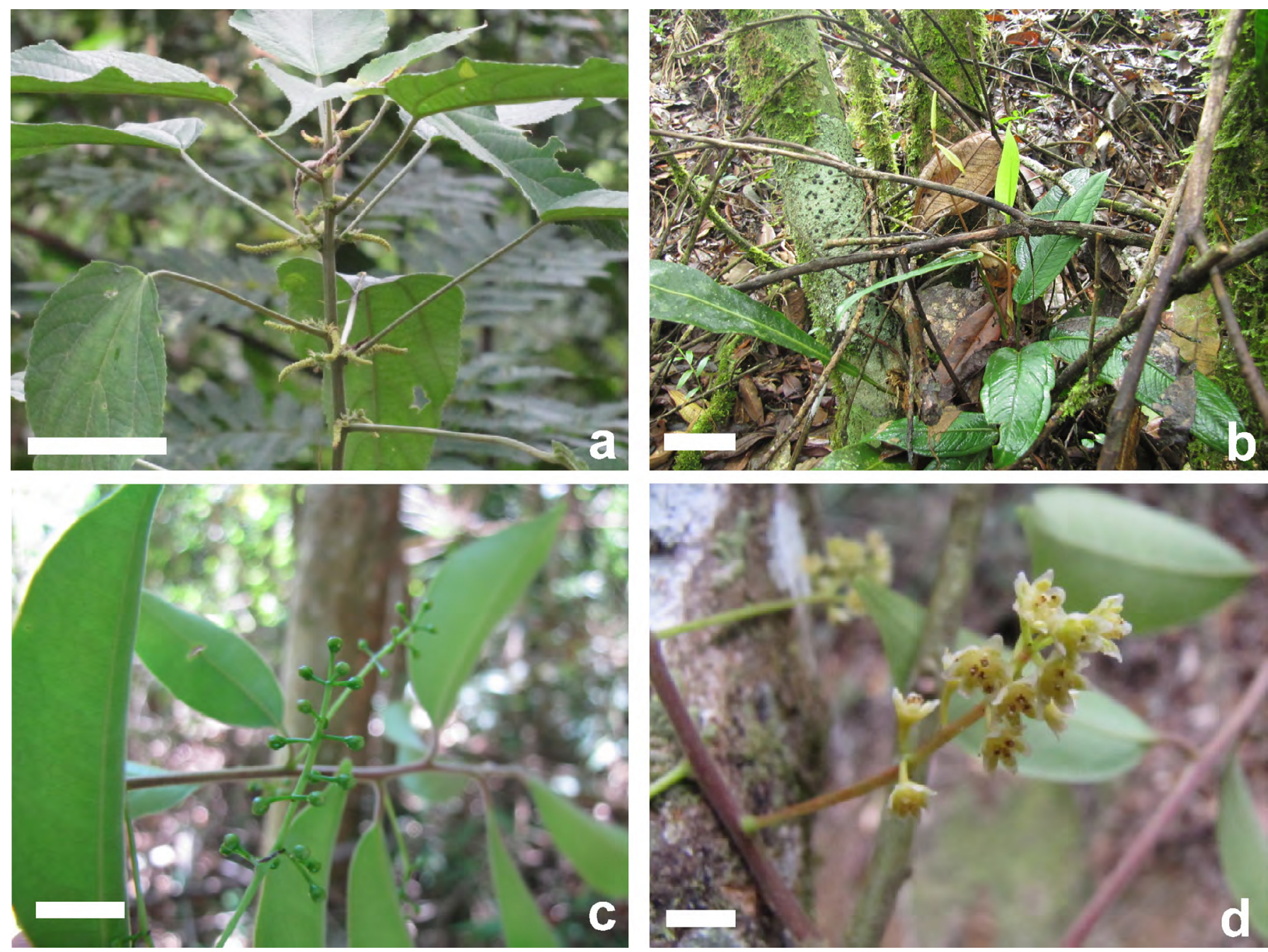

Figure 2. Acalypha amblyodonta (Müll.Arg.) Müll.Arg. a) General view of the inflorescence; Anthurium lucioi Nadruz. b) Habit. Ocotea villosa Kosterm. c) Inflorescence with flowers on bud. d) Inflorescence and flowers. Scale bar: a) $7 \mathrm{~cm}$, b) $8 \mathrm{~cm}$, c) $4 \mathrm{~cm}$, d) $1 \mathrm{~cm}$. 
Valentim, $20^{\circ} 20^{\prime} 16^{\prime \prime}$ S, $041^{\circ} 28^{\prime} 43^{\prime \prime}$ W, 20.II.2012, J.P.F. Zorzanelli 346 (VIES); Iúna, Serra do Valentim, $20^{\circ} 20^{\prime} 15^{\prime \prime}$ S, $041^{\circ} 28^{\prime} 43^{\prime \prime}$ W, 28.X. 2012, J.P.F. Zorzanelli 572 (VIES).

Anthurium lucioi Nadruz in Rodriguésia (60) 4: 835. 2009. (Figure 2b)

Terrestrial herb; stem covered with cataphylls; leaves simple, alternate, margin entire, blade lanceolate, base obtuse, apex acuminate, slightly prominent veins in the lower face, lightly; spadix and spathe yellow-green.

Notes: Anthurium lucioi is a very similar species to A. bragae Nadruz and A. marense K.Krause. Coelho et al. (2009) present the main morphologic differences between the referred species, especially in the form of the leafstalk, veins and leaf blade. A. lucioi, according to the same authors, occurs in the high mountain forests of the Atlantic coast, in moist and shady locations. The occurrence of the species was known from the states of Minas Gerais and São Paulo (Coelho et al. 2014).
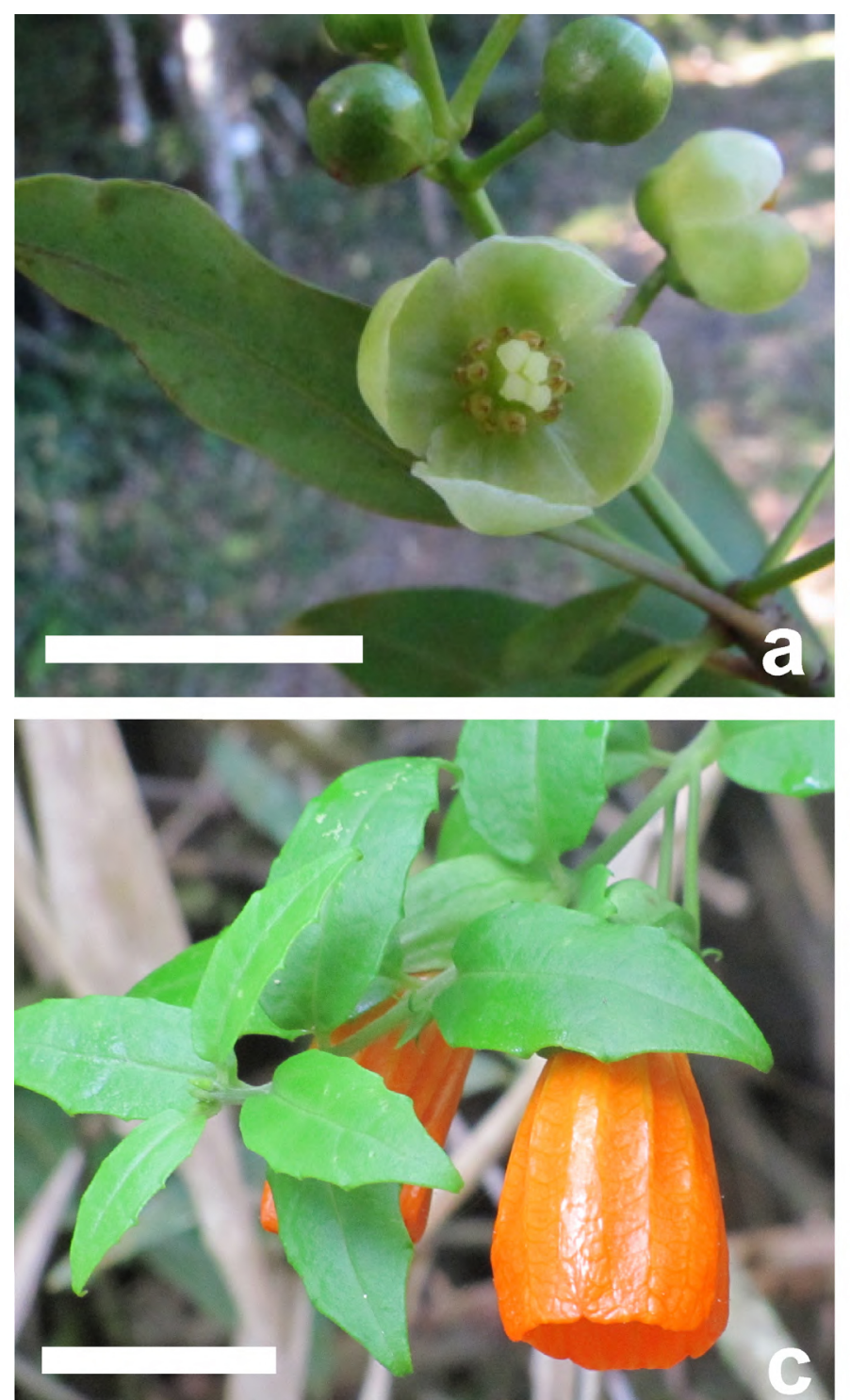

MATERIAL EXAMINED: Iúna, Serra do Valentim, 20²2'51" S, $041^{\circ} 28^{\prime} \mathrm{oo}^{\prime \prime}$ W, 20.VI.2013, J.P.F. Zorzanelli 779 (VIES; RB).

Cissus trianae Planch. in Monogr. Phan. 5(2): 555-556. 1887.

Liana, lenticelled stem, covered by sparsely puberulous indumentum; leaves trifoliate, alternate, blade lanceolate, base generally asymmetric, apex acuminated to mucronulate, margin slightly serrate; inflorescence umbellate, with greenish flower buds, flowers with short style; fruit green.

Notes: Cissus trianae is a distinct species with uncommon characteristics in comparison to the trifoliate species of the same genus (Lombardi 2000). It has Neotropical disjunct distribution to the Atlantic coast. It was known in Brazil from the states of São Paulo and Rio de Janeiro according to Lombardi (2014).

MATERIAl eXAMINed: Iúna, Serra do Valentim, $20^{\circ}$ $23^{\prime} 8^{\prime \prime}$ S, $041^{\circ} 28^{\prime} 03^{\prime \prime}$ W, 30.V.2013, J.P.F. Zorzanelli 700 (VIES; HRCB).
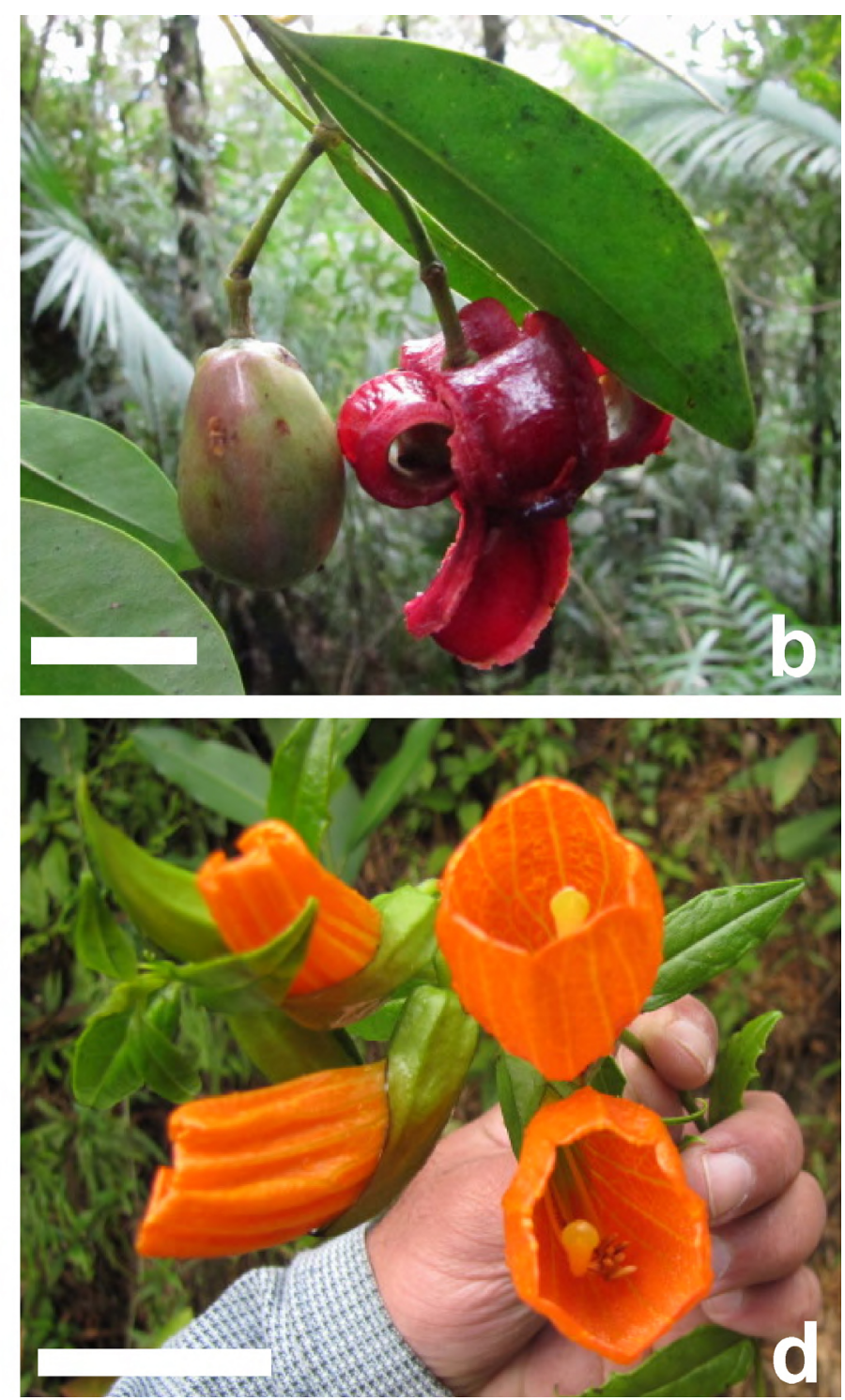

Figure 3. Tovomitopsis paniculata (Spreng.) Planch. \& Triana a) Flower in detail. b) Fruit in detail. Velloziella dracocephaloides (Vell.) Baill. c-d) Flowers in detail. Scale bar: a) $4 \mathrm{~cm}$, b) $3 \mathrm{~cm}$, c) $3.5 \mathrm{~cm}$, d) $3.5 \mathrm{~cm}$. 
Ocotea villosa Kosterm. in Bibliogr. Laurac. 1151. 1964. (Figure $2 \mathrm{c}$ and $2 \mathrm{~d}$ )

Shrub to tree 2.5-6 m; stem with villous indumentum, more evident in younger branches; leaves simple, alternate, with villous hair in the lower face and bald in the upper face, blade oval, elliptical or oval, base obtuse, apex cuspidate; inflorescence raceme cauliflorous.

Notes: Ocotea villosa was known from States of Rio de Janeiro and São Paulo (Quinet et al. 2014).

MATERIAL EXAMINED: Iúna, Serra do Valentim, $20^{\circ} 22^{\prime} 30^{\prime \prime} \mathrm{S}, 041^{\circ} 28^{\prime} 28^{\prime \prime} \mathrm{W}, 14$. VIII.2011, J.P.F. Zorzanelli 67 (VIES; RB); $20^{\circ} 21^{\prime} 55^{\prime \prime} \mathrm{S}, 041^{\circ} 28^{\prime} 26^{\prime \prime} \mathrm{W}, 03 . I X .2011$, J.P.F. Zorzanelli 95 (VIES; RB).

Tovomitopsis paniculata (Spreng.) Planch. \& Triana in Annales des Sciences Naturelles; Botanique, série 4 14: 262. 186o. (Figures 3a and $3 \mathrm{~b}$ )

Shrub to tree with yellow-green exudation; stem glabrous; leaves opposite, blades elyptic to lanceolated, margin entire, base and apex acuminate; bracteoles oval-triangular, apex acute; flowers 4-merous, showy; capsule with exposed seed and fixed when opened.

Notes: Tovomitopsis paniculata is a species endemic to Brazil with known distribution for the states of Minas Gerais, Rio de Janeiro and São Paulo (Bittrich et al. 2014).

MATERIAL EXAMINED: Iúna, Serra do Valentim, $20^{\circ} 21^{\prime} 53^{\prime \prime}$ S, $041^{\circ} 28^{\prime} 23^{\prime \prime}$ W, 19.I.2012, J.P.F. Zorzanelli 289 (VIES); $20^{\circ} 22^{\prime} 07^{\prime \prime} \mathrm{S}, 041^{\circ} 28^{\prime} 38^{\prime \prime} \mathrm{W}, 23 . I V .2011$, J.P.F. Zorzanelli 4 (VIES); $20^{\circ} 21^{\prime} 53^{\prime \prime} \mathrm{S}, 041^{\circ} 28^{\prime} 23^{\prime \prime} \mathrm{W}, 11 . X I I .2011$, J.P.F. Zorzanelli 224 (VIES).

Velloziella dracocephaloides (Vell.) Baill. in Mart., Fl. Bras. 8(2): 404-405. 1897. (Figures 3c and 3d)

Liana, stem quadrangular with hirsute hairs; leaves lanceolate, subopposed to opposed, blade with base slightly attenuated, apex truncate, margin short-spinous, with sparsely distributed scabrous hairs on the veins of lower face; inflorescence as a single axillary flower.

Notes: Souza and Giulietti (2009) inform that $V$. dracocephaloides was collected only in the States of São Paulo and Rio de Janeiro. Souza (2014) expands its distribution to Minas Gerais.

MATERIAL EXAmined: Iúna, Serra do Valentim, $20^{\circ}$ $22^{\prime} 49^{\prime \prime}$ S, $041^{\circ} 28^{\prime} 03^{\prime \prime}$ W, 16.IX.2011, J.P.F. Zorzanelli 123 (VIES).

Acalypha amblyodonta is a species with wide geographic distribution and occurs in states adjacent to Espírito Santo, as well as in Argentina (Lucena \& Alves 2010). The previous lack of records for this species from Espírito Santo may be explained by the scarceness of field efforts in various regions of the state. Velloziella dracocephaloides and A. lucioi (Souza \& Giulietti 2009; Coelho et al. 2009) are species with restricted distributions to Minas Gerais, Rio de Janeiro and São Paulo states and Minas Gerais and São Paulo states, respectively. This may result from specificity for habitats with environmental limitations, or preferences of these species for preserved areas. Cissus trianae has a Neotropical distribution, disjunctly occurring between the set of Andine formations and Central America and the Brazilian Atlantic coast (Lombardi 2000). In Brazil, its distribution is restricted to states of Espírito Santo, Rio de Janeiro and São Paulo. These new records indicate the importance of floristic studies not only in the Atlantic Forest remnant of Serra do Valentim, but also in the biome as a whole. The local floras should be stimulated and collection efforts in remnants located in private properties should be intensified. Information of this nature will broaden the understanding regarding the geographic distribution and preservation status of various species as well as provide refined data bases of the Brazilian flora.

\section{ACKNOWLEDGEMENTS}

We thank the experts Dr. Marcus Nadruz (Araceae), Dr. Débora Medeiros (Euphorbiaceae), Dr. Alexandre Quinet (Lauraceae), Dr. Elsie Franklin Guimarães and M.Sc. Valderes Bento Sarnaglia Junior (Piperaceae), Dr. Mário Gomes (Rubiaceae) and Dr. Júlio Lombardi (Vitaceae) for their effort in the determination of the materials; to CAPES for the concession of a masters' scholarship to the first author; to Post-Graduation Program in Forest Sciences, CCA/UFES, for granting logistic and laboratory support; to Marcos Lima Pereira for the map preparation.

\section{LITERATURE CITED}

Bittrich, V.; Trad, R.J.; Cabral, F.N.; Nascimento-Jr, J. E.; Souza, V.C. 2014. Clusiaceae; In: Lista de espécies da flora do Brasil. Jardim Botânico do Rio de Janeiro. Accessed at http://reflora.jbrj.gov. br/jabot/floradobrasil/FB689o, 24 July 2014.

Brade, A.C. 1947. Contribuição para o conhecimento da flora do estado do Espírito Santo (I. Pteridophyta). Rodriguésia 10(21): 25-56.

Cardiel, J.M. 2014. Acalypha in Lista de Espécies da Flora do Brasil. Jardim Botânico do Rio de Janeiro. Accessed at http://reflora. jbrj.gov.br/jabot/floradobrasil/FB17439, 24 July 2014

Chiron, G.R. and R.X. Bolsanello. 2011. Autres nouveautés pour l'Espírito Santo dans Le genre Acianthera (Orchidaceae). Richardiana 11(2): 84-97. http://richardiana.com//pdfRich/ Richardiana-vol13-19-FloraBrasil.pdf

Chiron, G.R. 2013. Contribution à l'inventaire de la flore d'Orchidaceae d'Espírito Santo (Brésil). Richardiana 13: 198-207. http:// richardiana.com//pdfRich/Richardiana-vol13-19-FloraBrasil.pdf

Coelho, M.A.N., J.L. Waechter and S.J. Mayo. 2009. Revisão taxonômica das espécies de Anthurium (Araceae) seção Urospadix subseção Flavescentiviridia. Rodriguésia 6o(4): 799-864. http:// rodriguesia.jbrj.gov.br/FASCICULOS/rodrig6o_4/o03-o8.pdf

Coelho, M.A.N. 2010. A família Araceae na Reserva Natural Vale, Linhares, Espírito Santo, Brasil. Boletim do Museu de Biologia Mello Leitão 28: 41-87. http://www.museudebiologiamelloleitao. gov.br/boletim/arquivos/28/Artigo-3_Nadruz_Coelho_28.pdf

Coelho, M.A.N., L.G. Temponi and T.A. Pontes. 2014. Anthurium in Lista de Espécies da Flora do Brasil. Jardim Botânico do Rio de Janeiro. Accessed at http://reflora.jbrj.gov.br/jabot/ floradobrasil/FB4951, 24 July 2014 
Couto, D.R., V.C. Manhães, F.C. Favoreto and A.P.G. Faria. 2013. Checklist of the Bromeliaceae from Pedra dos Pontões, Mimoso do Sul, Espírito Santo, Brazil, with four first records for the state. Biota Neotropica 13(4): 113-120. doi: 10.1590/S1676-06032013000400012

Fabris, L.C. and A.L. Peixoto. 2013. Sapotaceae das restingas do Espírito Santo, Brasil. Rodriguésia 64(2): 263-283. http://rodriguesia-seer. jbrj.gov.br/index.php/rodriguesia/article/view/ID\%20576

Forzza, R.C., Baumgratz, J.F.A., Bicudo, C.E.M., Carvalho-Jr., A.A., Costa, A., Costa, D.P., Hopkins, M., Leitman, P.M., Lohmann, L., Maia, L.C., Martinelli, G., Menezes, M., Morim, M.P., Coelho, M.A.N., Peixoto, A.L., Pirani, J.R., Prado, J., Queiroz, L.P., Souza, V.C., Stehmann, J.R., Sylvestre, L.S., Walter, B.N.T. \& Zappi, D. 2010. Catálogo de plantas e fungos do Brasil. Vol.1. Rio de Janeiro: Instituto de Pesquisas Jardim Botânico do Rio de Janeiro.

Forzza, R.C., Baumgratz, J.F.A., Bicudo, C.E.M., Carvalho-Jr., A.A., Costa, A., Costa, D.P., Hopkins, M., Leitman, P.M., Lohmann, L., Maia, L.C., Martinelli, G., Menezes, M., Morim, M.P., Coelho, M.A.N., Peixoto, A.L., Pirani, J.R., Prado, J., Queiroz, L.P., Souza, V.C., Stehmann, J.R., Sylvestre, L.S., Walter, B.N.T. \& Zappi, D. 2010. Catálogo de plantas e fungos do Brasil. Vol.2. Rio de Janeiro: Instituto de Pesquisas Jardim Botânico do Rio de Janeiro.

Fraga, C.N. and A.L. Peixoto. 2004. Florística e ecologia das Orchidaceae das restingas do estado do Espírito Santo. Rodriguésia 55(84): 5-20. http://www.jstor.org/stable/23497128

Freitas, J., E.J. Lírio and F. González. 2013. A new cauliflorous species of Aristolochia (Aristolochiaceae) from Espírito Santo, Brazil. Phytotaxa 124(1): 55-59. doi: 10.11646/phytotaxa.124.1.7

Giareta, A. and C.N.Fraga. 2014. Two new Eugenia species (Myrtaceae) from the Brazilian Atlantic Forest. Phytotaxa 163(2): 113-120. doi: 10.11646/phytotaxa.163.2.5

Goldenberg, R. and M. Reginato. 2006. Sinopse da família Melastomataceae na Estação Biológica de Santa Lúcia, Santa Teresa, Espírito Santo. Boletim do Museu de Biologia Mello Leitão 20: 33-58. http://www.museudebiologiamelloleitao.gov. br/boletim/arquivos/20/MBML_20_Goldenberg.pdf

Goldenberg, R. and M. Reginato. 2013. A new reptant species of Leandra (Melastomataceae, Miconieae) from the Atlantic Forest, southeastern Brazil. Phytotaxa 94(1): 23-29. doi: 10.11646/ phytotaxa.94.1.3

Hickey, M. and C. King. 2002. The Cambridge illustrated glossary of botanical terms. Cambridge: Cambridge University Press. 208 pp.

Holmgren, P.K, N.H. Holmgren, L.G. Bainett. 1990. Index Herbariorum. Part. I: the herbaria of the world. 8th edition. New York: New York Botanical Garden. 704 pp.

Kollmann, L.J.C. 2006. Begoniaceae da Estação Biológica de Santa Lúcia, município de Santa Teresa, Estado do Espírito Santo, Brasil. Boletim do Museu de Biologia Mello Leitão 20: 7-25. http://www.museudebiologiamelloleitao.gov.br/boletim/ arquivos/20/MBML_2o_Kollmann.pdf

Krahl, A.H., G. Pani, G.R. Souza and A.J.D. Cogo. 2012. A família Bromeliaceae em um fragmento florestal no município de Cachoeiro de Itapemirim, Espírito Santo, Brasil. Natureza on line 10(2): 92-103. http://www.naturezaonline.com.br/natureza/conteudo/ pdf/10_KrahlAHetal_093_103.pdf

Leme, E.M.C., C.N. Fraga, L.J.C. Kollmann, G.K. Brown, W. Till, O.B.C. Ribeiro, M.C. Machado, F.J.S. Monteiro and A.P. Fontana. 2010. Miscellaneous new species in the Brazilian Bromeliaceae. Rodriguésia 61(1): 21-67.

Lima, A.L. and J.J. Soares. 2003. Aspectos florísticos e ecológicos de palmeiras (Arecaceae) da Reserva Biológica de Duas Bocas, Cariacica, Espírito Santo. Boletim do Museu de Biologia Mello Leitão 16: 5-20. http://www.museudebiologiamelloleitao.gov.br/ boletim/arquivos/16/Lima\&Soares.pdf

Lombardi, J.A. 200o. Vitaceae: gêneros Ampelocissus, Ampelopsis e Cissus. Flora Neotropica Monograph 80: 1-250. New York: New
York Botanical Garden Press.

Lombardi, J.A. 2014. Vitaceae in Lista de Espécies da Flora do Brasil. Jardim Botânico do Rio de Janeiro. Accessed at http://reflora. jbrj.gov.br/jabot/floradobrasil/FB15269, 24 July 2014.

Lucena, M.F.A. and M. Alves. 2010. Notas taxonômicas para Euphorbiaceae s.l. do Nordeste do Brasil. Hoehnea 37(1): 71-85. doi: 10.1590/S2236-89062010000100005

Machado, A.F.P. and M.D.M. Viana Filho. 2012. Dorstenia romaniucii (Moraceae), a new species from the Brazilian Atlantic Rain Forest. Systematic Botany 37(2): 451-455. doi: 10.1600/036364412X635494

Marquete, R. and V.F. Mansano. 2010. A new species of Casearia (Salicaceae) from southeastern Brazil. Novon 20(2): 179-181. doi: 10.3417/2009011

Meirelles, J. and R. Goldenberg. 2012. Melastomataceae do Parque Estadual do Forno Grande, Espírito Santo, Brasil. Rodriguésia 63(4): 831-855. http://rodriguesia-seer.jbrj.gov.br/index.php/rodriguesia /article/view/ID\%20409

Meirelles, J., L.J.C. Kollmann and R. Goldenberg. 2012. Tibouchina tedescoi: a new species in Tibouchina sect. Pleroma (Melastomataceae) from Espírito Santo, Brazil. Kew Bulletin 67: 461-465. doi: 10.1007/s12225-012-9375-3

Müller, A. 1874. Euphorbiaceae; vol. 11(2): 1-751, in: C.F.P. von Martius (ed.). 1847-1850. Flora Brasiliensis, enumeration plantarum in Brasilia .... Monachii/Lipsiae: R. Oldenbourg. http://biodiversitylibrary.org/page/144748

Quinet, A., J.B. Baitello, P.L.R. Moraes, F.M. Alves and L. Assis. 2014. Lauraceae; in: Lista de espécies da flora do Brasil. Jardim Botânico do Rio de Janeiro. Accessed at http://reflora.jbrj.gov. br/jabot/floradobrasil/FB8494, 24 July 2014.

Reginato, M. and R. Goldenberg. 2013. Two new species of Leandra s.str. (Melastomataceae) from the Atlantic Forest in Espírito Santo, Brazil. Blumea 57: 210-214.

Rossini, J. 2010. Levantamento florístico das Gesneriaceae do município de Santa Teresa, Espírito Santo, Brasil [M.Sc. dissertation]. Viçosa: Universidade Federal de Viçosa. 66 pp.

Ruschi, A. 1986. Orquídeas de estado do Espírito Santo. Rio de Janeiro: Expressão e Cultura. $278 p p$.

Souza, V.C. and A.M. Giulietti. 2009. Levantamento das espécies de Scrophulariaceae sensu lato nativas do Brasil. Pesquisas, Botânica 6o: 7-288.

Souza, V.C. 2014. Orobanchaceae; in: Lista de espécies da flora do Brasil. Jardim Botânico do Rio de Janeiro. Accessed at http:// reflora.jbrj.gov.br/jabot/floradobrasil/FB12437, 24 July 2014.

SpeciesLink. 2014. Base de dados eletrônica. Accessed at http://www. splink.org.br, 10 March 2014.

Stehmann, J.R. and L.L. Giacomin. 2012. Markea atlantica (Solanaceae): a new species of tribe Juanulloeae disjunct from its core distribution. Systematic Botany (37)4: 1035-1042.

Valadares, R.T., M.L.L. Martins and M.A.N. Coelho. 2012. Levantamento das espécies de Araceae ocorrentes no Morro do Convento da Penha, município de Vila Velha-ES, Brasil. Natureza on line 10(1): 12-22.

Zorzanelli, J.P.F. 2012. Florística e estrutura de um fragmento de Floresta Ombrófila Montana na Serra do Valentim, Iúna, Espírito Santo [M.Sc. dissertation]. Jerônimo Monteiro: Universidade Federal do Espírito Santo. 133 pp.

Authors' contribution statement: JPZ and TTC collected the data, identified the specimens and wrote the text; ED and AGS assisted in the writing of the manuscript.

\footnotetext{
Received: September 2014

Accepted: April 2015

Academic editor: João Iganci
} 